\title{
Observing Micro, Small, and Medium Enterprises (MSMEs) Readiness to Support Cashless Society
}

\author{
Shinta Maurizka Chairunnisa ${ }^{1}$; Alfina ${ }^{2 *}$; Annisa Yasmin ${ }^{3}$ \\ ${ }^{1,2}$ Management Department, Universitas Internasional Semen Indonesia \\ Kompleks PT. Semen Indonesia (Persero) Tbk \\ Jl. Veteran, Gresik, Jawa Timur, 61122, Indonesia \\ ${ }^{3}$ Management Vocational Program, Universitas Diponegoro \\ Jl. Prof. Soedarto, SH., Semarang, Jawa Tengah 50275, Indonesia \\ 1shintamaurizka97@gmail.com; ²alfina@uisi.ac.id; ${ }^{3}$ annisayasmin@lecturer.undip.ac.id
}

Received: $25^{\text {th }}$ September 2020/ Revised: $23^{\text {rd }}$ November 2020/ Accepted: $25^{\text {th }}$ November 2020

How to Cite: Chairunnisa, S. M., Alfina., \& Yasmin, A. (2020). Observing Micro, Small and Medium Enterprises (MSMEs) readiness to support cashless society. The Winners, 21(2), 101-106. https://doi.org/10.21512/tw.v21i2.6722

\begin{abstract}
Digital transformation in the era of the industrial revolution 4.0, has led to various new phenomena in today's people's lifestyle, including the payment transaction system. Realizing that Micro, Small and Medium Enterprises (MSMEs) had been one of the economy's pillars in Indonesia, the government was trying to maximize the role of MSMEs to support the realization of a digital transaction ecosystem in Indonesia. With a phenomenological approach, the descriptive qualitative research aimed to provide in-depth observation and analysis on the readiness process of MSMEs in Tuban, East Java in adopting digital payment technology to support the realization of the trend of a cashless society. The results show that culture, social influence, and acceptance of technology are the dominant factors affecting the readiness process of MSMEs in Tuban in adopting digital payment technology.
\end{abstract}

Keywords: Micro Small Business Enterprises (MSMEs), cashless society, technology acceptance, digital payments

\section{INTRODUCTION}

Payment transactions towards a cashless society is a new phenomenon to provide efficiency in the financial sector (Alfina, 2020). It is also a recent innovation that enables customers and merchants make a financial transaction for goods and services electronically (Priananda et al., 2020).

For this reason, Bank Indonesia has introduced new banknotes, which certainly cost a lot of material due to the process of making new money. This is inefficient since the government has to spend a lot of money to print new money every year. The existence of non-cash transactions, it is possible that the costs of printing new money can be allocated for other needs.

Cost savings due to the existence of a non-cash payment system, which cuts costs of printing and distributing cash, cash handling, and administrative management will help denomination of the country (Ika, 2017).

People often seem to pratice financial transactions using cashless payment system, starting from payment for transportation systems, access to parking, purchasing fast food, online shopping transactions and several other payment transactions through shops or service providers cooperating with electronic money provider companies. The cashless payment system is a behavioral change of people in eliminating the usage of money and allowing payment technology (Kumari \& Khanna, 2017).

Thomas, Jain and Angus (2013) point out three indicators in this framework to measure the progress of cashless development consisting of: a) Share, which means measuring the percentage of the value of non-cash payments by customers; b) Trajectory, which means measuring the shift in cash payment transactions made by customers; c) Readiness, which measures the level of a state's readiness to move from cash payment transactions to non-cash payment transactions through access to financial services, macroeconomic and cultural factors, scale of trade and competition, as well as technology and infrastructure.

Based on the categories and indicators described, each country can be categorized based on the results of measuring the three indicators. There are four categories, namely: 1) inception/initial level, when 
non-cash transactions are less than $40 \%$; 2) transition level, when non-cash transactions reach $40-60 \%$; 3 ) tipping point level, when non-cash transactions reach $60-80 \%$; 4) nearly-cashless level, where more than $80 \%$ of payment transactions have used non-cash.

Found in Thomas et al. (2013), readiness is measured by the level of a state's readiness to move from cash payment transactions to non-cash payment transactions through access to financial services, macroeconomic and cultural factors, scale of trade and competition, as well as technology and infrastructure.

Xena and Rahadi (2019) point out that the readiness factor or readiness of Indonesia in adopting a non-cash payment system is still at the initial level with a value of 24 out of 100 . In their research, Xena and Rahadi put forward a conceptual framework related to the factors that influence the readiness of MSMEs (Micro, Small and Medium Enterprises) in Indonesia towards a cashless society. There are six MSMEs readiness factors in adopting non-cash payment technology, namely: performance expectancy, culture, acceptance of technology, social influence, perceived security, and effort expectancy. Since people in Indonesia have not shown rapid progress regarding to readiness to become cashless society, there is a need for shortcut to accelerate it, for example innovation from providers and government action (Abbas, 2017).

Realizing that MSMEs are one of the pillars of the economy in Indonesia that provide huge contribution, along with the growing era of digitalization, the government has made programs to maximize the role of MSMEs in the current digital transformation era to support its realization. One of digital transaction ecosystems in Indonesia is the UMKM Go Online program. UMKM Go Online is also a government strategy to realize the government's vision, namely Go Digital Vision 2020 as a means for the government to become the largest digital economy country in Southeast Asia.

Tuban is one of the areas in East Java that has been reached by several online platform and been potential of MSMEs growing in the food and beverage sector. The economy in Tuban is considered relatively low with a UMR of around Rp.2.500.000,00 (Badan Pusat Statistik Kabupaten Tuban, 2019). Non-cash transaction activities have also developed in Tuban, marked by the majority of minimarkets, supermarkets, even cafes and restaurants in Tuban City that have provided EDC (Electronic Debit Card) machines, but non-cash transaction is still considered a rare activity.

The potential for MSMEs in Tuban to develop their business through the UMKM Go Online program is large, but non-cash transaction activities using digital payments are still not widespread, one of the evidence is shown by several SMEs that actually have EDC machines or mobile phones to support non-cash transactions but these EDC machines tend to be hidden so that buyers are not aware of the availability of noncash payment instruments at these outlets. The store employees' answers are obtained on average because the machine often got errors and the amount of money disbursed in the buyer's account has been reduced by the administrative fees charged by the bank. It is found that several MSMEs in the occurrence of the UMKM Go Online program phenomenon along with the cashless society phenomenon has resulted in efforts to maximize the adoption of digital technology in society, especially MSMEs which are a strong pillar of the Indonesian economy.

The UMKM Go Online program is also proclaimed as a form of adaptation to the phenomenon of shifting people's shopping behavior patterns that lead to an online shopping system. The presence of various online service platforms in the form of selling products and services has increased the desire of people who want to be fast-paced. By the existence of smart phones that can support the mobility of today's society, business players in Indonesia are required to adapt quickly to be able to deal with the increasing competition.

The research aims to specifically and deeply analyze the readiness factor that matter the most among MSMEs in the food and beverage sector in Tuban as one of enterprises that currently play a leading role in developing countries' economic growth (Abbasov \& Alizadia, 2016).

\section{METHODS}

The explorative research design is related to the readiness process of MSMEs and what they are dealing with in adopting technology. In this context, the technology discussed is digital payment transaction technology using a qualitative descriptive research method with a phenomenological approach (Malhotra, 2010).

The research uses primary data sources, namely data directly collected by researchers from the first source through depth interviews. Referring to Igudia (2017), the primary data sources are best explained by qualitative research because they can gain a deep understanding of the problem that confronts the researcher. The food and beverage sector is chosen since it is a legitimate sector that many cashless payment providers have chosen to take action to "burn money" to attract consumers to try cashless payments.

As seen in Table 1, the informants are owners or management from three categories of MSMEs (Micro, Small and Medium Enterprises) in the food and beverage sector. They are divided into MSMEs that have applied digital payment technology to explore which process to make them ready to become merchants supporting cashless payments. Not to mention this research explores the obstacles encountered by the MSMEs with manual payment system.

The research begins with the preparation stage to find the phenomenon as the research object, namely the phenomenon of the digital era and the trend of cashless society from the perspective of MSMEs in the food and beverage sector occurs to be the dominant sector in Tuban, East Java. 
The lack of information regarding the development of digital payment technology in Tuban raises a big question mark whether Tuban is ready to adopt digital payment.

A problem is formulated to find out how the readiness process of MSMEs in East Java in adopting digital payment technology. Based on the problem formulation, a research model is compiled in accordance with the research objectives, which is to conduct a more specific and deep analysis related to the readiness process of the food and beverage sector MSMEs in Tuban in adopting digital payment technology.

After determining the research design, the selected informant should belong to one of these characteristics - the owner or person in charge - of the MSME food and beverage sector in Tuban with the micro, small and medium category. Data collection techniques are carried out by in-depth interviews with informants which aim to review previous theories and research as the fundamental.

The six SME readiness factors (Xena \& Rahadi, 2019) are divided into several details question to ask more whether this factor was being their concerns while making decision to accept cashless transaction. For example of culture factors, informants are deeply asked about how the location and the store's surrounding influence the owner to decide the payment system. After that, the research carried out data analysis and validation using triangulation of internal data sources.

Table 1 The Informant

\begin{tabular}{clc}
\hline $\begin{array}{c}\text { Informant } \\
\text { Name }\end{array}$ & Name of Business & Business Size \\
\hline A & RM. Mina Agung & Medium \\
B & ID Cafe & Small \\
C & Coffee Scope & Micro \\
D & Dandiya Cafe & Small \\
\hline
\end{tabular}

\section{RESULTS AND DISCUSSIONS}

Based on information from the Central Statistics Agency (BPS) of Tuban, East Java in 2019, the UMR (Regional Minimum Wage) of Tuban is at a nominal value of Rp.2.500.000,00. This shows that the economy of the people of Tuban can be considered low. However, the use of non-cash transactions has begun to grow in Tuban with the existence of programs initiated by private banks in Tuban. In supporting its massive implementation in Tuban, a form of government has cooperated through the National Payment Gateway with Bank Jatim in Tuban. The launch of QRIS (Quick Response Code Indonesian Standard) carried out simultaneously in all districts in East Java is expected to be a strategy for the realization of a better non-cash transaction process through a digital system (Priscilla, 2019).
Although, there are many food and beverage MSMEs in Tuban, this does not necessarily mean that the use of technology is important. Currently, the usage in business operational activities remains poor. The readiness factor of human resources also seems to have influenced the decision to adopt technology in business processes.

For micro and small food businesses in Tuban, the recruitment process rarely follows professional human resource recruitment procedures. Instead, only the closest people are most likely to be recruited as employees. Companies put aside specifications and capabilities since they consider the value element of giving help in it.

Based on the findings, the main problem of MSMEs in Tuban due to human resources being unfamiliar with technology is also an impact. The nature of the Tuban population remains very closely related to the culture of upholding the norm of decency and helping each other.

Although several entrepreneurs in the food and beverage sector have used digital payment technology as well as internet marketing, their numbers are relatively small. In general, knowledge about technology, especially information systems and digital payment technology, is considered quite low so that many MSMEs players may not realize the real benefits in developing their business.

The rapid development of technology should be able to trigger the high use of technology as it becomes easier to use. The current reality cannot reflect the situation where technology has been widely used in the operational activities of MSMEs. The occurring reality raises questions to try tracing back to the early readiness of MSMEs to use technology. Many phenomena show that the type of industry and the size of the company do not guarantee the availability of adequate technology as a tool for doing business. Guariglia, Liu and Song (2011) state that companies with financial limitations and difficulties to get funding from outside the company will reduce their level of investment. One of the investments that MSMEs might reduce is the allocation of technology development. On this basis, there is the possibility of a lack of technology use by MSMEs due to financial constraints from internal parties and difficulty in obtaining outside funding.

MSMEs players have realized the use of information technology related to non-cash payment systems to support their business activities. All informants express the same intention even though with an emphasis on several different things as the basis for the process of adopting digital payment technology.

Informants are reluctant to use digital payment technology based on simple thoughts that their business is still running even though they do not invest in any technology. The informant states that if the size of the company have been large, an electronic payment system would be needed.

Adequate facilities and access to information 
in the process of adopting digital payment technology are a separate consideration for informants. Although all informants state that digital payment technology is useful, its procurement is not needed for their current company size. In addition, they consider it unnecessary to invest in digital payment technology facilities. In addition to facilities, human resource capabilities need to be improved to be able to take advantage of digital payment technology.

Several incidents of digital payment technology have also happened during the implementation in Tuban since the difficulty to obtain related information on providers is quite a tough consideration for some informants. However, it seems not a big deal for well-educated informants to obtain information about digital payment technology. In this case, knowledge of the pros and cons of implementing electronic payment systems in business will have a different impact on each informant. There are informants who use digital payment technology as a marketing strategy in terms of providing good experiences for consumers. Electronic Data Capture (EDC) is chosen for payment since it is considered easier. Sufficient knowledge can be used to use digital payment systems in this regard.

Informants have priority in implementing noncash transactions using digital payment technology. Some informants prioritize human resources in the process of implementing digital payment technology. Meanwhile, there are informants who prioritize in choosing the media for recording transactions. These are the benefits for businesses by using digital payment technology to make informants focus on certain advantages.

The system helps in the development process of the business. Digital payment technology influences informants to consider the progress of their business. Well-educated informants with more personal experience in the use of technology occur to encounter less unpleasant experiences, which slightly affect the use of digital payment technology.

For informants who understand the concept of cost-benefit, digital payment technology will be utilized based on interests and needs. For them, the costs incurred by digital payment technology are not a problem (within the limits of financial capacity), which meas as long as they meet their needs, digital payment technology will be used. This decision still considers the cost aspect. The social environment, such as consumers of their business, also becomes their main consideration in using digital payment technology.

Implicitly, all informants express the same thing that the use of digital payment technology might help increase customer satisfaction if they could provide more effective and efficient services.

One of the informants states that he needs several additional systems to be further assisted by the application of digital payment technology that is currently in use and is more stable and smoother. Consumers are a trigger for the use of digital payment technology because consumer satisfaction is considered to decrease if service runs slowly.

Collaboration between the community and business actors is essential for the realization of this cashless society trend in Tuban, East Java. Most of the population in Tuban are still not familiar with digital payment technology, especially in the food and beverage business since a gap has been formed. On one hand, business actors think of providing digital payment technology if consumers are ready and accustomed to using it. On the other hand, consumers think that they are ready, but the facilities not yet available from MSMEs. Not to mention the urge to use digital payments, such as cashback promos and discounts, has not reached consumers, from the observation on consumer opinion on the restaurants or cafes.

Out of the six factors mentioned by Xena and Rahadi (2019), there are three dominant factors that underlie the readiness process of MSMEs in Tuban, in adopting the trend of digital payments to support the trend of a cashless society. They include culture, social influence, and acceptance of technology, as seen in Figure 1.

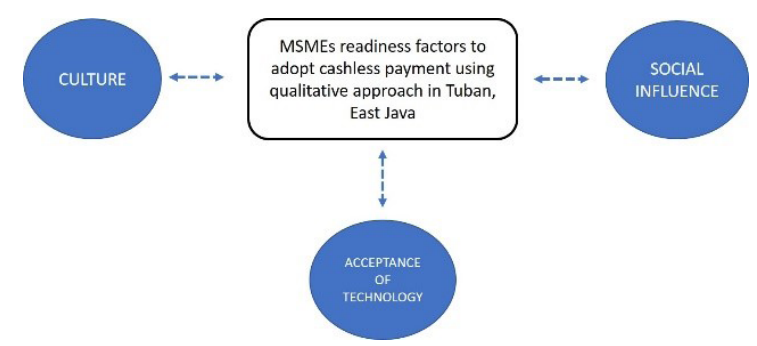

Figure 1 Tuban MSMEs' Readiness Factors

The modification of the conceptual framework depicted in Figure 1 is an adjustment of the condition of MSMEs in Tuban, East Java in adopting digital payment technology.

The culture that comes from within the organization and from their consumers is the reason why they are not ready to use digital payment technology. From what has been conveyed by the informants, it is concluded that the readiness or unpreparedness of MSMEs in adopting cashless payments depends on the response of the consumer first, as in the economic principle, if there is demand then supply will surely follow. This concept is what also happens to the people of Tuban. Consumers are heading in this direction, but it needs acceleration which must also be done by the government to provide socialization accordingly.

For social influence factor, it can be concluded that before someone decide to use a technology, they would previously get encouragement from the social environment around them. Junaidi (2015) shows that society has an influence on individuals in deciding the use of technology. Social influence can come from family, coworkers, relatives and other social environments that are directly adjacent to the individual. In adopting non-cash digital payment transaction system technology, MSMEs owners 
certainly have considerations coming from their surroundings regarding platforms that are suitable to support their businesses. Based on the exposure of the three informants, it can be concluded that the social influence in using digital payment technology comes from consumers and their business stakeholders, such as raw material suppliers who still use cash in transactions. Moreover, the acceptance of technology starts becoming one of the considerations of MSMEs since they see many consumers in their stores have not yet rely on the cashless payment system, which means they are conservative.

\section{CONCLUSIONS}

There are three dominant factors that affect the readiness of Tuban MSMEs in adopting digital payment technology to support the realization of a cashless society trend, namely: 1) cultural factor; 2) social influence factor; and 3) technology acceptance factor.

The research considers cultural factor since its object is dominated by MSMEs, so the habit of collecting cash remains popular rather than collecting money cashless. The suburban demographic factors are found to explain differences in readiness to use digital financial services (Trinugroho et al., 2017).

Next, social influence factor is motivated by the social environment around MSMEs conducting their business operations. Consumers in Tuban who are accustomed to using cash in transactions affect the willingness of MSMEs to use digital payment services and the lack of ability of human resources capable to operate technology.

The last one is the factor of technology acceptance at MSMEs. The intensity of non-cash transaction activities is considered low in Tuban, indicating that the digital ecosystem has not been wellrealized. This is what makes MSMEs stay reluctant to adopt digital payment technology. In addition, access to information from digital distribution technology service providers remains unclear. In other words, it lacks of promotion and marketing communication strategies, so the people in Tuban receive less socialization. In addition, the same condition happens in Singapore, which $\mathrm{Ng}$ (2018) finds that adoption of electronic payments in Singapore fails since only few merchants are prepared to accept modes of cashless payment.

It is concluded the readiness of MSMEs in the food and beverage sector in Tuban is influenced by cultural factors, social influences and acceptance of technology. The government is expected to collaborate with digital payment transaction service providers to build a better non-cash transaction ecosystem by providing adequate access to information for the public. If the non-cash transaction ecosystem is strong, a culture that shapes the social character of the community will be created, so the trend of a cashless society in Tuban can immediately be realized.

\section{REFERENCES}

Abbas, A. E. (2017). Literature review of a cashless society in Indonesia: Evaluating the progress. International Journal of Innovation and Technology Management, 8(3), 193-196. https://doi.org/10.18178/ ijimt.2017.8.3.727.

Abbasov, A. \& Alizada, T. (2016). Small and mediumsized enterprises as an influential factor towards the economic growth of countries with transition economies. Economic and Social Development: Book of Proceedings, 453.

Alfina. (2020). From physical to digital: Consumer adoption process to e-wallet. Proceedings of the $23^{\text {rd }}$ Asian Forum of Business Education (AFBE 2019). https:// doi.org/10.2991/aebmr.k.200606.003.

Badan Pusat Statistik Kabupaten Tuban. (2019, December 23). Statistik Daerah Kabupaten Tuban 2019. https://tubankab.bps.go.id/publication/2 019/12/23/9c327e3644d451600e02f3e2/statistikdaerah -kabupaten-tuban-2019.html

Guariglia, A., Liu X., \& Song, L. (2011). Internal finance and growth: Microeconometric evidence on Chinese firms. Journal of Development Economics, 96(1), 7994. http://dx.doi.org/10.1016/j.jdeveco.2010.07.003.

Igudia, P. O. (2017). A qualitative evaluation of the factors influencing the adoption of electronic payment systems (SMEs) by SMEs in Nigeria. European Scientific Journal, 13(31), 472. https://doi. org/10.19044/esj.2017.v13n31p472.

Ika, A. (2017, October 3). Layanan pembayaran non-tunai berkelanjutan untuk efisiensi ekonomi Indonesia. KOMPAS.com. https://ekonomi.kompas.com/ $\mathrm{read} / 2017 / 10 / 03 / 150445226 /$ layananpembayarannon-tunai-berkelanjutan-untuk-efisiensi-ekonomi.

Junaidi, S. (2015). A model of factors influencing the consumer's intention to use the e- payment system in Indonesia. Procedia Computer Science, 59(1), 214220. https://doi.org/10.1016/j.procs.2015.07.557.

Kumari, N. \& Khanna, J. (2017). Cashless payment: A behavioural change to economic growth. International Journal of Scientific Research and Education, 5(7). http://ijsae.in/index.php/ijsae/ article/view/197.

Malhotra, N. K. (2010). Marketing Research: An Applied Orientation ( $6^{\text {th }}$ Ed.). Pearson Education India.

$\mathrm{Ng}$, D. (2018). Evolution of digital payments: early learnings from Singapore's cashless payment drive. Journal of Payments Strategy and Systems, 11(4), 306-312. Research Collection Lee Kong Chian School of Business. https://ink.library.smu.edu.sg/ $1 \mathrm{kcsb}$ research/6198/.

Priananda I., Stevani, M., Sutanto, T., \& Mariani, M. (2020). Grassroots economy towards cashless society: An empirical analysis of micro-merchant's readiness in continuing the usage of cashless payment system. International Journal of Scientific \& Technology Research, 9(3), 929-928. https://www.ijstr.org/ final-print/mar2020/Grassroots-Economy-TowardsCashless-Society-An-Empirical-Analysis-OfMicro-merchants-Readiness-In-Continuing-The- 
Usage-Of-Cashless-Payment-System.pdf.

Priscilla, K. (2019, August 23). BI targetkan penerapan QRIS merata di Jawa Timur pada 2020. Liputan6. com. https://surabaya.liputan6.com/read/4045371/ bi-targetkan-penerapan-qris-merata-di-jawa-timurpada-2020.

Thomas, H., Jain, A., \& Angus, M. (2013). Measuring progress toward a cashless society. MasterCard Compendium. https://newsroom.mastercard.com/ wp-content/uploads/2014/08/MasterCardAdvisorsCashlessSociety-July-20146.pdf.

Trinugroho, I., Sawitri, H. S., Toro, M. J., Khoiriyah, S., $\&$ Santoso, A. B. (2017). How ready are people for cashless society? Jurnal Keuangan dan Perbankan, 21(1). https://www.neliti.com/publications/116235/ how-ready-are-people-for-cashless-society\#cite.

Xena, P. \& Rahadi, A. R. (2019). Adoption of e-payment to support Small Medium Enterprise payment system: A conceptualised model. International Journal of Accounting, Finance and Business, 4(18), 32-41. http://www.ijafb.com/PDF/IJAFB-2019-18-03-04. pdf. 